\title{
Особенности внутренней политической ситуации в Ираке в период с 1920 по 2003 гг.
}

\author{
Джанаби Я.С.Х., Надир М.С.Э. \\ Национальный исследовательский Нижегородский государственный университет \\ им. Н.И. Лобачевского, \\ Россия, 603005, Нижний Новгород, улица Ульянова, 2 \\ E-mail: yacoobsabih@gmail.com; e-mail: nmse90@mail.ru
}

\begin{abstract}
Аннотация. Данное исследование призвано прояснить детали наиболее важных этапов изменений во внутренней политике Ирака с 1920 по 2003 годы. На протяжении почти всего XX столетия Ирак подвергался многократным сменам власти, а также влиянию событий, имевших место в других государствах региона, что в сумме привело страну к внутреннему хаосу и нестабильности, сопровождавшимися продолжительными раздорами среди этнических, религиозных и социальных групп. В ходе работы были проанализированы ранее не упоминавшиеся источники, что позволило получить новые подробности о предмете исследования. Дополнительные детали событий и точки зрения на них позволили ещё раз оценить влияние различных факторов на создание обстановки в стране и на развитие её отношений с внешним миром. Становится более заметна неспособность Ирака своими силами справиться с нарастающим внутренним кризисом, что привело мировое сообщество к принятию решения о вынужденном внешнем вмешательстве.
\end{abstract}

Ключевые слова: Ирак, Арабский мир, политическая ситуация, оккупация, конфликт, внешнее вмешательство.

Для цитирования: Джанаби Я.С.Х., Надир М.С.Э. 2021. Особенности внутренней политической ситуации в Ираке в период с 1920 по 2003 год. Via in tempore. История. Политология. 48 (4): 911-920. DOI: 10.52575/2687-0967-2021-48-4-911-920.

\section{Features of the internal political situation in Iraq in the period from 1920 to 2003}

\author{
Yaqoob Sabeeh Hasan Janabi, Mohammed Salah Eddin Nadir \\ Lobachevsky State University of Nizhny Novgorod - National Research University, \\ 2 Ulyanova St., Nizhny Novgorod 603005, Russia \\ E-mail: yacoobsabih@gmail.com; e-mail: nmse90@mail.ru
}

\begin{abstract}
This study is intended to clarify details of the most important stages of changes in the internal policy of Iraq from 1920 to 2003. Throughout almost the entire 20th century, Iraq was subjected to multiple changes of power, as well as the influence of events that took place in other states of the region, which in total led the country to internal chaos and instability, accompanied by prolonged discord among ethnic, religious and social groups. In the course of the work, previously unknown sources were analyzed, which allowed us to obtain new details about the subject of the study. Additional details of the events and points of view on them were shown, which helped to show differently the influence of various factors on the creation of the situation in the country and the development of its relations with the outside world. The inability of Iraq to cope with the growing internal crisis on its own is becoming more noticeable, which led the world community to make a decision on forced external intervention.
\end{abstract}

Keywords: Iraq, Arab world, political situation, an occupation, conflict, external interference. 
For citation: Janabi Y.S.H., Nadir M.S.E. 2021. Features of the internal political situation in Iraq in the period from 1920 to 2003. Via in tempore. History and political science. 48 (4): 911-920 (in Russian). DOI: $10.52575 / 2687-0967-2021-48-4-911-920$.

На протяжении всей истории Ирак был центром диалога и встреч цивилизаций [Shamkhi, 2019]. Но из-за своего привилегированного положения на политической карте он превратился в постоянное поле битвы с шестнадцатого века до 1918 года. В тот момент конфликт между османскими турками и персидскими Сефевидами усилился после передачи Персии контроля над шиитскими святынями в Наджафе, являвшимися символом Сефевидов. Всё это время османы пытались сохранить Ирак в качестве суннитской буферной зоны против распространения соперничающей секты [Kane, 2011]. После падения Османской империи и ввода британских войск в Ирак страна стала раздробленной, с жестокими конфликтами между племенами. Одной из причин была попытка президента США Вудро Вильсона управлять Ираком как британской колонией с привлечением на второстепенные руководящие должности индийских чиновников, не нанимая на места иракцев.

Объектом данного исследования является изучение политических проблем, с которыми столкнулся Ирак, начиная с 1920 года и до прихода в Багдад американских войск в 2003 году [Suleiman, 2017].

Основная цель исследования состоит в поиске ответа на вопрос, какие политические проблемы были наиболее важными в Ираке с 1920 по 2003 годы, а также от чего пострадал Ирак, учитывая, что политическая ситуация является основой стабильности во всех других сферах жизни. Результаты исследования могут оказать поддержку в понимании текущей ситуации в стране и выборе наиболее подходящих её решений.

Поиск новых данных по указанной проблеме является актуальным, так как исследований, проясняющих наиболее важные политические этапы, через которые прошел Ирак с 1920 по 2003 год, недостаточно.

25 апреля 1920 года Великобритания получила мандат на государство Ирак. По мере распространения информации о вступлении в силу этого мандата националистическая активность усилилась. Религиозный лидер издал указ (фетва), в котором утверждалось, что правление немусульман в мусульманской стране противоречит исламским законам, и призывал к джихаду [Johnson, 2004]. После того, как сунниты и шииты временно отложили в сторону свои разногласия, религиозные лидеры призвали их к действию через патриотические проповеди.

Революция 1920 года стала поворотным моментом в современной истории Ирака впервые к ней присоединились сунниты и шииты, целые племена и города [Scott, 1995]. Политический хаос, оставленный революцией, вынудил высокопоставленных британских чиновников в Багдаде реализовать планы по созданию иракского национального государства с арабской монархией, а также разработать конституцию и договор, которые узаконили бы британское правление в стране. 17 августа 1921 года королём Ирака был назначен Фейсал І. Ирак стал монархией.

Период с 1921 по 1936 гг. был отмечен стабильностью, которая вынудила королей Ирака поддерживать хорошие отношения с британцами в качестве обязательного правительства. Но в середине 1930-х годов на Ближнем Востоке произошел первый военный переворот, прошедший под руководством Бакра Сидки, и именно Ирак стал арабской страной, в которой начались перемены.

Переворот Бакра Сидки в 1936 году важен по следующим причинам. Иракская армия была очень крупной националистической фигурой в политике правительства. Таковой она оставалась до 1941 года [Jones, 2018] благодаря поддержке и преклонению иракцев, особенно в рядах самой армии. Многие офицеры иракской армии обратили свой интерес к политике после того, как обнаружили, что репутация армии в подавлении ассирийского 
восстания в городе Мосул явилась политическим преимуществом. Большинство влиятельных офицеров были арабскими националистами, вдохновившими многих младших офицеров. Все они последовали примеру соседних Турции и Ирана, где процветали военные диктатуры. Под руководством генерал-майора Бакра Сидки армия свергла иракское правительство. Осенью 1936 года начался период военного вмешательства в политику. После того как военные осознали, что переворот предоставил более эффективный способ объединения раздробленного государства и модернизации общества, отсталого от конституционной демократии и свободного предпринимательства, авторитарный режим приобрел мощное влияние. Особенно это было справедливо для исламской страны с её специфическими традициями и проблемами [Sorby, 2015]. Во время Второй мировой войны и противостояния между странами нацистского блока и союзниками вспыхнуло восстание, которое изменило ход истории Ирака. Возглавляемое Рашидом Али аль-Гайлани и офицерами «Золотого квадрата» при поддержке начальника Генерального штаба генераллейтенанта Хусейна Фаузи, оно излучало дух национального единства Ирака с арабскими странами - Ирак согласился на концепцию независимости от Великобритании, от стратегического сотрудничества и союза с ней. Великобритания вмешалась в последнюю минуту, подорвав победу национально-освободительного движения под руководством альГайлани. Часть Ирака оказалась под британской оккупацией, в результате чего британские либеральные партии господствовали еще семнадцать лет. Всё это негативно повлияло на внутреннюю ситуацию, обострив политические и социальные проблемы, подогревавшие недовольство народной оппозиции.

В июле 1958 г. вспыхнуло новое освободительное движение, которое возглавила нелегальная национальная организация офицеров под предводительством Абдула Карима Касима [Scott, 1995]. Революция 14 июля 1958 г. положила конец иракской монархии, исключив Ирак из Багдадского пакта и переориентировав внешнюю политику Ирака в сторону от Запада. Для совершения переворота Абд аль-Карим Касим воспользовался сложившейся обстановкой. Опасаясь того, что во время ливанского кризиса 1958 года сирийские силы двинутся вдоль границы Ирака, король Фейсал II и премьер-министр Нури асСаид приказали армии мобилизоваться для развертывания у западной границы страны. Оба войсковых соединения, получивших приказ на дислокацию, находились под общим командованием Адула Карима Касима. Их путь должен был проходить недалеко от Багдада. Воспользовавшись пробелом в безопасности, созданным этой мобилизацией, генералмайор Касем и полковник Абдель Салам Ареф использовали секретную группу «Свободные офицеры», сформированную Гамалем Абдель Насером, для захвата радиостанции, королевского дворца и других важных объектов в столице, чтобы контролировать ключевые точки в Багдаде. В ходе дворцового переворота были убиты король, регент Абдул Иллах и все члены королевской семьи. Касим возглавил новое правительство, Ирак стал республикой [The story of the removal..., 2019].

После успеха революции генерала Касима Соединенные Штаты становились всё более обеспокоенными предполагаемой угрозой вторжения коммунистической идеологии в Ирак. Коммунистическая партия Ирака существовала, но режим Нури Саида жестоко подавил ее. Чтобы положить конец потенциальной опасности коммунизма в Ираке, Вашингтон поспешил свергнуть Абделя Карима по договоренности с Гамалем Абдель Насером через полковника Абдула Салама Арефа. Ареф был сторонником Гамаля Абдель Насера, арабиста, и хотел свержения Абдель Карима Касима - у них было давнее личное противостояние. Он стремился присоединиться к Объединенной Арабской Республике, но Касим не был в этом заинтересован и явно отверг любую идею передачи власти Насеру. Арефа поддержала националистическая партия БААС, Касима же поддержала коммунистическая партия Ирака [Allah, 2019]. В январе 1959 года Ареф был арестован по обвинению в попытке свержения правительства и приговорен к смертной казни, а затем к пожизненному заключению за недостаточностью доказательств. Позже Абдул Карим Касим 
смягчил приговор и перевел Арефа из тюрьмы в дом, где тот в дальнейшем находился под домашним арестом.

После 8 февраля 1963 года (известном также как Рамадановая революция), который был запланирован и осуществлен Арабской социалистической партией БААС в сотрудничестве с независимым национальным движением и военным руководством, Ареф был избран президентом республики.

Ранее во время правления Абдула Карима Касима произошло восстание курдов под предводительством муллы Мустафы Барзани, в результате которого отношения между Эрбилем и Багдадом стали напряженными, хотя в начале революции 1958 года они были хорошими. В июле напряженность достигла пика, и армия решила нанести удар по курдской вооруженной группировке в северном регионе. Курдское восстание против правительства Багдада вспыхнуло во всех регионах северного Ирака. Рынки и фабрики были разрушены, курды жили в политическом хаосе. Восстание длилось 17 месяцев подряд - до падения режима Абдула Карима Касима в 1963 году [Khoshnik, 2017].

После успешного переворота в 1963 году Ареф, став вторым президентом в истории Республики Ирак, сформировал новое правительство, в которое вошел его брат Абд аль-Рахман Ареф. К 1964 году новый президент провёл чистку в рядах армии и правительства от членов партии БААС и заменил их насеритскими офицерами. В его союзе с насеритами главной целью было воспроизвести египетско-сирийский союз 1958 года и объединить Ирак с Египтом. В июле 1964 года правительство приняло закон, требующий объединения всех политических партий страны. Иракский арабский социалистический союз национализировал природные ресурсы государства, а также все банки и компании. Новый президент попытался использовать ту же тактику, которую использовал Касим во время своего пребывания в должности, чтобы расчистить для себя политическую почву. К 1965 году Ареф, заметив усиление насеритов на политической арене и почувствовав в этом угрозу, уволил их с постов.

В 1966 году президент Абдул Салам погиб в результате крушения вертолета на юге Ирака [Abdallat, 2020]. Во время консенсуса Совета национальной обороны его брат Абд аль-Рахман Ареф стал новым президентом Ирака [Al-Itawi, 2015]. Абд аль-Рахман Ареф максимально сохранил национальное единство, социальный мир, факторы экономического развития и цивилизованного прогресса. Его правление было совершенно свободным от столкновений и конфликтов [Al-Jawadi, 2014].

Но не прошло и двух лет, как баасисты быстро отстранили его от власти. Переворот 1968 года стал новым началом для Саддама Хусейна, которому еще до переворота была поручена ответственность за группу из партии Баас, занимающуюся вопросами разведки и контрразведки, так называемый режим Саддама [Ash-Shakraji, 2005]. Что отличает переворот 17 июля 1968 года от других переворотов, так это отсутствие кровопролития некоторые исследователи описали его как «белый переворот» [As-Sabawi, 2019]. Так было положено начало тридцатипятилетнему правлению Баас. За это время была создана прочная система, отличавшаяся от предыдущих форм правления. Факт того, что многие участники переворота 1968 года были родом из племён, имел сильное влияние на их понимание путей сохранения власти в будущем. Трое из пяти членов-учредителей Совета революционного командования, правящего органа партии Баас, принадлежали к племени Аль-Бу Насир из Тикрита. Они обнаружили, что могут использовать традиционную клановую солидарность для создания лояльной системы, которая позволит им консолидировать свою власть [Norman, 2016].

После того, как партия Баас взяла под свой контроль правительство, она поспешила положить конец курдской революции, заключив соглашение об автономии. С одной стороны, требовалось закрепление контроля над гражданской, политической и военной поддержкой страны, а с другой - ослабить напряженность в северном Ираке. Под давлением партии БААС, Саддам Хусейн в марте 1970 года заключил соглашение с ДПК (Демокра- 
тическая партия Курдистана), названное «Мартовский договор». Соглашение об автономии 1970 года удовлетворило большинство требований Барзани [Kadura, 2016]. Однако спокойствие между Багдадом и Эрбилем вскоре закончилось после того, как на фоне подписания соглашения между Советским Союзом и Ираком о дружбе и сотрудничестве, шах Ирана выдвинул новую инициативу по ослаблению Ирака и вооружению иракских курдских повстанцев. Этот шаг удивил Соединенные Штаты.

Когда шах и его союзники начали свою деятельность, первый начал убеждать Киссинджера и Никсона не допустить этот союз. Израильтяне, вооружавшие и обучавшие видную курдскую группировку с 1960-х годов для подрыва Ирака, были на стороне Ирана. Курдское восстание вынудило иракские войска штурмовать дома, ослабив совместное арабское наступление на Израиль. Барзани, в свою очередь, опасался намерений Ирана, пока США не вынудили его встать на опасный путь открытого противостояния [Esty, 2017]. Шах Мухаммед Реза Пехлеви надеялся оказать давление на иракское правительство в продолжающемся пограничном споре. Три года спустя шах подписал соглашение о границе с Багдадом и прекратил поставки оружия курдам. Курдский лидер Мустафа Барзани обратился к госсекретарю США Генри Киссинджеру за поддержкой, но американцы отказались оказать ему помощь.

В 1974 году в Багдаде, в продолжение Мартовского договора, в одностороннем порядке был принят закон, не устроивший курдов, и они начали новое восстание. Оно было подавлено правительством Ирака, подписавшим в 1975 году с Ираном Алжирский договор, подразумевавший прекращение поддержки курдским повстанцам со стороны Ирана [Mroue, 2019]. Одно из важнейших положений Алжирского соглашения - разграничение сухопутных и морских границ с Ираком. Это соглашение было в интересах Ирана, и из-за него Ирак потерял большую часть своей земли и большую часть Шатт-эль-Араб [Barzani, 2002]. Тысячи курдских боевиков и их семьи были вынуждены бежать в Иран, спасаясь от иракской армии [Kinsley, 1991]. Около 200000 курдов бежали в Иран, 40000 из них насильно вернулись в Ирак. Призывы о помощи и убежище в США игнорировались.

В 1979 году в ходе Исламской революции шах был изгнан из Ирана и больше участия в делах страны не принимал. Позже у него был обнаружен рак, и свои последние дни он провёл в скромном доме в Маклине [Schorr, 1991] до своей смерти в марте 1979 года [The very rare moment..., 1980]. На смену ему президентом Ирана был избран Абольхасан Банисадр. Саддам Хусейн обвинил Иран в «отказе от соглашения о выводе войск из регионов, граничащих с Ираком, которое обязывает Ирак ничего не делать». Слова Саддама Хусейна указывают на опасный рост напряженности между странами. В то же время президент Ирана Абольхасан обвинил Ирак в подготовке к «интенсивному нападению» на регион Хузестан. В 1979 году Ирак начал более серьезно относиться к вопросу о границах, очевидно, пользуясь слабым положением Ирана. В частности, после прошедших в рядах иранской армии в течение 18 дней революции, чистки и полного отделения от США, поставлявших Ирану большую часть оружия вплоть до падения шаха в феврале [Ottaway, 1980].

Трудно сказать, был ли готов Иран к войне. Вначале была предпринята попытка уничтожить иранскую авиацию, применив тактику блицкрига, одновременно атаковав 10 иранских авиабаз. Но поскольку эти атаки не увенчались успехом, иракские сухопутные войска проникли к границе Ирана и начали оккупировать стратегические районы. Изза внутренней чистки Иран потерял половину своих руководящих элементов в начале ирано-иракской войны, что нанесло серьезный удар по возможностям иранской армии в начале войны. Половина боевых пилотов, служивших в иранских ВВС, была арестована в результате политики администрации Хомейни. Иран уступил Ираку превосходство в воздухе. Война длилась с 1980 по 1988 гг. и отбросила Иран по крайней мере на 10 лет назад, оставив после себя множество проблем. Ирак и Иран потеряли по полмиллиона человек каждый [Pirinçс̧i, 2015]. 
16 марта 1988 года иракский самолет пролетел над городом Халабджа - долиной, окруженной горами, полностью защищенной от остальной части Ирака. Самолеты сбросили на город несколько химических бомб. Дым появился сразу после приземления снарядов. Применённый газ действовал быстро, вызывая удушье. В последующие дни фотографии людей и животных, ставших жертвами химических атак, появлялись по телевидению и публиковались в газетах по всему миру. Позже было подсчитано, что от 3200 до 5000 мирных жителей были убиты в результате нападения и от 7000 до 10000 получили ранения. Бомбардировка Саддамом собственного народа химическим оружием вызвала гнев во всем мире [Security Council Resolution..., 1987]. 18 июля 1988 г. Иран объявил о принятии резолюции 598 Совета Безопасности [Øygarden, 2014].

Ирак вышел из войны в очень сложной ситуации, поскольку иракская экономика, города и инфраструктура были разрушены, и Ирак остро нуждался в деньгах для восстановления страны [Baker III, 1995]. За этим последовало приостановление помощи Ираку в Персидском заливе и демобилизация значительной части его армии после окончания войны с Ираном [Gause III, 2001]. Армия осталась без работы, а долги Ирака увеличились на 80 миллиардов долларов, в том числе 40 миллиардов долларов странам Персидского залива. Все эти причины побудили Саддама Хусейна задуматься о вторжении в Кувейт с целью получения денег [Al-Rumaihi, 1994].

2 августа иракские войска вторглись в Кувейт [Al-Rumaihi, 1997]. Иракская оккупация Кувейта длилась семь месяцев [Saddam Hussein's Defiance..., 1991-1997]. На протяжении всего этого периода Саддам Хусейн отказывался полностью выполнять резолюцию 660 Совета Безопасности о незаконном вторжении Ирака в Кувейт, как и все последующие резолюции. Эта резолюция в том числе уполномочивала государства-члены ООН «использовать все необходимые средства для поддержки и выполнения Резолюции 660 и всего, что следует за ней».

С этим связаны последующие решения по восстановлению международного мира и безопасности. В результате непримиримости Ирака и его нежелания освободить Кувейт, Соединенные Штаты Америки сформировали коалицию для свержения иракской армии [Michael, 2003]. Удар США полностью разрушил иракскую армию. В результате международных бомбардировок было убито более 30000 солдат, уничтожены мосты, заводы, общественные объекты и прочая инфраструктура Ирака [Awad, 2012]. Помимо катастрофических последствий, последовавших за этой войной, Совет Безопасности ООН с помощью резолюции 6616 августа 1990 г. [Al-Samurai, 1991] ввел экономические санкции против Ирака, от которых страна страдала в течение 13 лет [Micah, 2016]. США призвало иракскую армию и иракский народ взять дело в свои руки и вынудить диктатора Саддама Хусейна уйти в отставку. Послание Буша Ираку транслировалось по всем международным теле- и радиоканалам, а самолеты коалиции сбрасывали листовки, призывающие иракских солдат и мирных жителей «заполнить улицы и переулки и свергнуть Саддама Хусейна и его помощников». Курды на севере и шииты на юге начали революцию после многих лет тайных планов свержения Саддама Хусейна. В ходе стычек повстанцев и правительства населенным пунктам были причинены серьезные разрушения, но бунтующие были вынуждены покинуть города.

В конце концов Саддам Хусейн, используя вертолеты, дальнобойную артиллерию и бронированные наземные силы, начал жестокое контрнаступление против восстания, убив 30-60 тысяч шиитов на юге и около 20 тысяч курдов на севере. К началу апреля 1991 года режим Саддама полностью подавил сопротивление шиитов и курдов [Maynard, 2005]. По другим данным, число погибших составило 300000 человек [Human Rights Watch, 1992]. Протестующие также совершили вандализм и многочисленные преступления. Около 70000 из них бежали в лагеря беженцев в Саудовской Аравии, Турции и Иране [Gareth, 2003]. После того как Саддам Хусейн подавил повстанцев, Организация Объединенных Наций приняла Резолюцию 688, в которой призвала правительство Ирака прекратить свою 
кампанию против гражданского населения и предоставить немедленный доступ в страну международным гуманитарным агентствам. В том же месяце Организация Объединенных Наций учредила «бесполётные зоны» на севере страны, чтобы защитить курдское население от действий Багдада.

После того как Соединенные Штаты прекратили все боевые действия в северном Ираке, иракское правительство вывело свой административный персонал из этого района. Курдам была предоставлена автономия резолюцией Совета Безопасности, и первые выборы в местные органы власти были проведены в 1992 году. Голоса Демократической партии Курдистана и Патриотического союза Курдистана были настолько близки, что ни одна из сторон не выиграла выборы. Между конкурирующими политическими партиями велись переговоры о самоуправлении до новых выборов [Norwegian Refugee..., 2002]. Но их соглашение о разделении власти и влияния вскоре рухнуло - между курдами началась гражданская война за контроль над провинциями Дахук, Эрбиль и Сулеймания, длившаяся с мая 1994 по 24 ноября 1997 года [Al-Dabbagh, 2020]. Вооруженный конфликт между двумя сторонами достиг апогея 31 августа 1996 года, когда Барзани попросил Саддама о военной поддержке для противостояния силам Патриотического союза Курдистана во главе с Талабани, который взял под контроль центральную провинцию Курдистана Эрбиль. Саддам ответил на призыв Барзани, и иракские силы нарушили бесполетные зоны международной коалиции. 31 августа 1996 года, через 6 лет после войны в Персидском заливе, на севере и юге страны примерно 30000 бронированных республиканских гвардейцев вошли в Эрбиль. Это была возможность для Саддама восстановить контроль над северными регионами страны и нанести поражение силам Талабани. Барзани смог восстановить контроль над городом Эрбиль. В результате почти 5000 человек погибли и тысячи получили ранения. Но иракские силы были вынуждены отступить под влиянием военной операции, начатой США, известной как «Удар в пустыне». Дохук и Эрбиль оказались под контролем ДПК, а Сулеймания - под контролем Национального союза [Prados, 1999].

В 1990-е годы по Ираку было нанесено несколько ударов. Несколько авиаударов совершили США в декабре 1998 года. Были атакованы многие военные объекты под предлогом того, что Ирак не соблюдает резолюции Совета Безопасности о нарушении бесполетной зоны на севере и юге страны и пытается помешать международным инспекторам искать оружие массового уничтожения [Bacevich, 2000]. США выражало уверенность в огромной способности Ирака производить, накапливать, обслуживать и доставлять оружие массового уничтожения. Операция носила название «Пустынный лист». В результате бомбардировок была ограничена способность Саддама Хусейна вести войну против своих соседей. Соединенные Штаты и Великобритания продолжали свою жестокую кампанию бомбардировок Ирака, нанося удары каждые два-три дня, якобы для выполнения резолюций Организации Объединенных Наций [Mamdukh, 2005]. Позже, в 2003 году, Колин Пауэлл в своем выступлении в Совете Безопасности предоставил аудио- и видеозаписи, являющиеся якобы вескими доказательствами того, что Ирак обладает оружием массового уничтожения. Это повлекло за собой новый конфликт США и Ирака. Новое обвинение было ничем иным как ложью, продвигаемой американскими лидерами, в чём они позже признались, но на тот момент оно прозвучало убедительно. Пауэлл попросил Совет Безопасности ООН принять резолюцию, разрешающую Соединенным Штатам и Великобритании начать войну в Ираке для уничтожения иракского оружия массового поражения, но на самом деле решение начать войну было принято задолго до отправки своих инспекторов ООН в Ирак [Al-Baradei, 2012].

Несмотря на стремления Ирака примирить враждующие слои населения и улучшить экономическое состояние страны, производимые им действия как на своей территории, так и на мировой арене, зачастую являлись следствием личных мировоззрений и противоречивых ценностей представителей власти, захватывающих правление страной в разные периоды XX века. Это не могло не привести не только ко внутренним беспорядкам, 
но и к конфликтам с другими странами, в том числе решившим воспользоваться в собственных интересах уязвимым состоянием Ирака.

\section{References}

1. Abdallat S.A. 2020. The role of tribalism and sectarianism in defining Iraqi national identity. Abstract. dis. ... Master's thesis. Harvard Extension School. 119.

2. Al-Baradei Mohamed. 2012 Time of deception. Nuclear diplomacy in times of betrayal. Dar es Salaam, printing \& publishing, Egypt, 252.

3. Al-Dabbagh Ahmed. 2020. Anniversary of the fighting of the Kurds. The day of Barzani's appeal against the Talabani forces. Al-Jazeera newspaper. URL: https://www.aljazeera.net/news/politics/2020/8/31/\%D8\%B0\%D9\%83\%D8\%B1\%D9\%89-

$\% \mathrm{D} 8 \% \mathrm{~A} 7 \% \mathrm{D} 9 \% 84 \% \mathrm{D} 8 \% \mathrm{AD} \% \mathrm{D} 8 \% \mathrm{~B} 1 \% \mathrm{D} 8 \% \mathrm{~A} 8$

\%D8\%A7\%D9\%84\%D8\%A3\%D9\%87\%D9\%84\%D9\%8A\%D8\%A9-

\%D8\%A8\%D9\%83\%D8\%B1\%D8\%AF\%D8\%B3\%D8\%AA\%D8\%A7\%D9\%86-

\%D8\%A7\%D9\%84\%D8\%B9\%D8\%B1\%D8\%A7\%D9\%82 (accessed: January, 2021) (in Arabic).

4. Al-Itawi V.Kh. 2015. Abdul Rahman Aref and his political role in Iraq in the period 1966-1968. Center for Secular Studies and Studies in the Arab World. https://www.ssrcaw.org/ar/print.art.asp?aid=472153\&ac=2 (accessed: January, 2021) (in Arabic).

5. Al-Jawadi Mohammed. 2020. Abdel-Rahman Aref ... the only Arab president, fulfilled the constitutional role of the king. URL: https://resalapost.com/2020/05/25/\%d8\%b9\%d8\%a8\%d8\%af$\% \mathrm{~d} 8 \%$ a7\%d9\%84\%d8\%b1\%d8\%ad\%d9\%85\%d9\%86-\%d8\%b9\%d8\%a7\%d8\%b1\%d9\%81-

$\% \mathrm{~d} 8 \% \mathrm{a} 7 \% \mathrm{~d} 9 \% 84 \% \mathrm{~d} 8 \% \mathrm{~b} 1 \% \mathrm{~d} 8 \% \mathrm{a} 6 \% \mathrm{~d} 9 \% 8 \mathrm{a} \% \mathrm{~d} 8 \% \mathrm{b3}-$

$\% \mathrm{~d} 8 \% \mathrm{a} 7 \% \mathrm{~d} 9 \% 84 \% \mathrm{~d} 8 \% \mathrm{~b} 9 \% \mathrm{~d} 8 \% \mathrm{~b} 1 \% \mathrm{~d} 8 \% \mathrm{a} 8 \% \mathrm{~d} 9 \% 8 \mathrm{a}-$

$\% \mathrm{~d} 8 \% \mathrm{a} 7 \% \mathrm{~d} 9 \% 84 \% \mathrm{~d} 9 \% 88 \% \mathrm{~d} 8 \% \mathrm{ad} \% \mathrm{~d} 9 \% 8 \mathrm{a} \% \mathrm{~d} 8 \%$ af-\%d8\%a7/ (accessed: January, 2021) (in Arabic).

6. Allah K.A. 2019. Abdul Karim Qasim, Saddam Hussein and the Kurdish state. Sot Al-Irak newspaper. URL: https://www.sotaliraq.com/2019/07/05/\%D8\%B9\%D8\%A8\%D8\%AF\%D8\%A7\%D9\%84\%D9\%83\%D8\%B1\%D9\%8A\%D9\%85-\%D9\%82\%D8\%A7\%D8\%B3\%D9\%85\%D9\%88\%D8\%B5\%D8\%AF\%D8\%A7\%D9\%85-\%D8\%AD\%D8\%B3\%D9\%8A\%D9\%86-

\%D9\%88\%D8\%AF\%D9\%88\%D9\%84\%D8\%A9-\%D8\%A7\%D9\%84\%D9\%83\%D8\%B1\%D8\%AF/ (accessed: January, 2021) (in Arabic).

7. Al-Rumaihi Mohammed. 1994. Echoes of the Kuwait war - Arab reactions to the invasion and its aftermath. Dar al saqi, 129 (in Arabic).

8. Al-Rumaihi Mohammed. 1997. Fall of illusions - Arabism after the Iraq's invasion of Kuwait. Madbuli Library, 375 (in Arabic).

9. Al-Samurai O. 1991. Wreckage of the East Gate and Facts about the Bad Times in Iraq. A new reading in the first and second Gulf Wars. No. 1: 324 (in Arabic).

10. Ash-Shakraji S.M. 2005. July 17, 1968, The return of al-Bakr and Saddam. Elav newspaper. URL: https://elaph.com/Web/ElaphWriter/2005/7/76740.html (accessed: January, 2021) (in Arabic).

11. As-Sabawi Hussein Saleh. 2019. «White coup» in Iraq (July 17-30, 1968). Alkhaleej newspaper.

URL: https://alkhaleejonline.net/\%D8\%A2\%D8\%B1\%D8\%A7\%D8\%A1/\%D8\%A7\%D9\%84\%D8\%A7\%D9\% 86\%D9\%82\%D9\%84\%D8\%A7\%D8\%A8-\%D8\%A7\%D9\%84\%D8\%A3\%D8\%A8\%D9\%8A\%D8\%B6\%D9\%81\%D9\%8A-\%D8\%A7\%D9\%84\%D8\%B9\%D8\%B1\%D8\%A7\%D9\%82-17-30-

\%D8\%AA\%D9\%85\%D9\%88\%D8\%B2-1968 (accessed: January, 2021) (in Arabic).

12. Awad A.R. 2012. Shaaban Uprising in Hill. Babil. No. 3: 6-7 (in Arabic).

13. Bacevich Andrew J. 2000. The Use of Force in the Clinton Era: Continuity or Discontinuity? Chicago Journal of International Law: Vol. 1: No. 2: 375.

14. Baker III James A. 1995. Politics of diplomacy. Translated by Magdie Sharcher. Madbuli Library. Cairo, Egypt, 687 (in Arabic).

15. Barzani Massoud. 2002. Mustafa Barzani and the Kurdish Liberation Movement (1931-1961), 745. (in Arabic).

16. Esty Jonathan C. 2017. Kissinger's Strategy in the Iraqi Kurdish Rebellion of 1972-75: False Start or Foundation of American-Kurdish Partnership? Harvey M. Applebaum '59 Award, 13. Yale university, 52. 
17. Gareth R.V. Stansfield. 2003. Iraqi Kurdistan. Political Development and Emergent Democracy. RoutledgeCurzon, 278.

18. Gause III F. Gregory. 2001. Iraq and the Gulf War: Decision-Making in Baghdad. Abstract. dis. ... Associate Professor of Political Science. University of Vermont, 34.

19. Human Rights Watch. 1992. Endless torment. The 1991 Uprising in Iraq and Its Aftermath. URL: https://www.hrw.org/reports/1992/Iraq926.htm (accessed: January, 2021).

20. Johnson Constance A. 2004. Iraq. Legal History and Tradition. Law Library of Congress. Center for Global Legal Research, 32.

21. Jones Scott. 2018. Occupation and Resistance in Southern Iraq: A Study of Great Britain Britain's civil Administration in the Middle Euphrates and the Great Rebellion of 1917-1920. Abstract dis. ... Master of Arts. College of Humanities and Social Sciences, DePaul University, 101.

22. Kadura E.Yu. 2016. Regional and international impact. On the Kurdish issue in Iraq (Example from practice 1972-1975). Arab Center for Research and Policy Studies, 34 (in Arabic).

23. Kane S. 2011. Previous Turkish-Iranian competition in Iraq. United States Institute of Peace, 13.

24. Khoshnik A. 2017. Historical roots of the Kurdish question. Egyptian Institute for Political and Strategic Studies. URL: https://eipsseg.org/\%D8\%A7\%D9\%84\%D8\%AC\%D8\%B0\%D9\%88\%D8\%B1-

\%D8\%A7\%D9\%84\%D8\%AA\%D8\%A7\%D8\%B1\%D9\%8A\%D8\%AE\%D9\%8A\%D8\%A9-

$\% \mathrm{D} 9 \% 84 \% \mathrm{D} 9 \% 84 \% \mathrm{D} 9 \% 82 \% \mathrm{D} 8 \% \mathrm{~B} 6 \% \mathrm{D} 9 \% 8 \mathrm{~A} \% \mathrm{D} 8 \% \mathrm{~A} 9-$

\%D8\%A7\%D9\%84\%D9\%83\%D8\%B1\%D8\%AF\%D9\%8A\%D8\%A9/ (accessed: January, 2021) (in Arabic).

25. Kinsley S.F. 1991. Whatever Happened To The Iraqi Kurds? URL: https://www.hrw.org/reports/1991/iraq/ (accessed: January, 2021).

26. Mamdukh T. 2005. When the lie is revealed. Al Bayan Emirates newspaper. URL: https://www.albayan.ae/opinions/2005-09-24-1.101353 (accessed: January, 2021) (in Arabic).

27. Maynard, B.P. 2005. The role of the ulama in Shiite social movements Bahrain, Lebanon, and Iraq. Abstract. dis. ... Master of arts in national security affairs. Naval postgraduate school. Monterey California, 101.

28. Micah Zenko. 2016. Remembering the Iraqi Uprising Twenty-Five Years Ago. Message. URL: https://www.cfr.org/blog/remembering-iraqi-uprising-twenty-five-years-ago (accessed: January, 2021).

29. Michael O. 2003. Estimating Casualties in a war to Overthrow Saddam. Elseiver Science Limited, 20.

30. Mroue B. 2019. For Kurds, US pull-back feels like being abandoned once more. URL: https://apnews.com/article/eccfbcac47914858a82304cb867dd85d (accessed: January, 2021).

31. Norman S.M. 2016. Understanding corruption in Iraq. Abstract. dis. ... Master of Arts in International Studies. Oklahoma University, 90.

32. Norwegian Refugee Council/Global IDP Project. 2002. Profile of internal displacement: Iraq. Compilation of the information available in the Global IDP Database of the Norwegian Refugee Council. Norwegian Refugee Council/Global IDP Project. Geneva - Switzerland, 91.

33. Ottaway D.B. 1980. Iraq Cancels Border Pact With Iran. The Washington Post. URL: https://www.washingtonpost.com/archive/politics/1980/09/18/iraq-cancels-border-pact-withiran/725d6c32-0a8c-4eab-afbf-0c05e2edd019/ (accessed: January, 2021).

34. Øygarden R.H. 2014. Chemical weapons and the Iran-Iraq war. A discussion of the UN Security Council's response to the use of gas in the Iran-Iraq war. Abstract. dis. ... Master's thesis in history. University of Bergen, 120.

35. Pirinççi F. 2015. Power Struggle in the Gulf: A Re-evaluation of the Iran - Iraq War. In: Journal of Academic Inquiries, No. 10(1): 231-245.

36. Prados A.B. 1999. Iraq: Post-War Challenges and U.S. Responses, 1991-1998. Congressional Research Services. The Library of Congress, 32.

37. Saddam Hussein's Defiance of United Nations Resolutions. 1991-1999. URL: https://georgewbush-whitehouse.archives.gov/infocus/iraq/decade/sect2.html.

38. Scott J.C. 1995. Great Britain and the Rashid Ali al-Kilani uprising in the spring of 1941. Abstract. dis. ... Master of Arts in History. Portland State University, Germany, 115. 
39. Schorr D. 1991. 1975 Background to betrayal. The Washington Post. URL: https://www.washingtonpost.com/archive/opinions/1991/04/07/1975-background-to-betrayal/aa973065ea5e-4270-8cf9-02361307073c/?utm_term=.8726078b2f5d (accessed: January, 2021).

40. Security Council Resolution 598: Iraq-Islamic Republic of Iran. 1987.

41. Shamkhi A.S. 2019. Geographical position of Iraq. Babil, 3 (in Arabic).

42. Sorby K. Jr. 2010. Iraq's First Coup Government (1936-1937). Ministry of Foreign Affairs of the Slovak Republic Hlboká cesta 2, Bratislava, Slovakia, 23.

43. Suleiman A. 2017. Iraq: Roots of Internal Conflict. Egyptian Research Institute. URL: https://eipss-eg.org/\%D8\%A7\%D9\%84\%D8\%B9\%D8\%B1\%D8\%A7\%D9\%82-

$\% \mathrm{D} 8 \% \mathrm{AC} \% \mathrm{D} 8 \% \mathrm{~B} 0 \% \mathrm{D} 9 \% 88 \% \mathrm{D} 8 \% \mathrm{~B} 1-$

\%D8\%A7\%D9\%84\%D8\%B5\%D8\%B1\%D8\%A7\%D8\%B9\%D8\%A7\%D8\%AA-

\%D8\%A7\%D9\%84\%D8\%AF\%D8\%A7\%D8\%AE\%D9\%84\%D9\%8A\%D8\%A9/ (accessed: January, 2021) (in Arabic).

44. The story of the removal of Abdeslam Aref and the amendments of the Ministry of July 1958-time. Azzaman newspaper, Baghdad. October 1, 2019. URL: https://www.azzaman.com/\%D9\%82\%D8\%B5\%D8\%A9-

\%D8\%A5\%D9\%82\%D8\%B5\%D8\%A7\%D8\%A1-\%D8\%B9\%D8\%A8\%D8\%AF-

\%D8\%A7\%D9\%84\%D8\%B3\%D9\%84\%D8\%A7\%D9\%85-\%D8\%B9\%D8\%A7\%D8\%B1\%D9\%81-

$\% \mathrm{D} 9 \% 88 \% \mathrm{D} 8 \% \mathrm{AA} \% \mathrm{D} 8 \% \mathrm{~B} 9 \% \mathrm{D} 8 \% \mathrm{AF} \% \mathrm{D} 9 \% 8 \mathrm{~A} \% \mathrm{D} 9 \% 84 \% \mathrm{D} 8 \% \mathrm{~A} 7 \% \mathrm{D} 8 \% \mathrm{AA}-$

\%D9\%88\%D8\%B2\%D8\%A7/ (accessed: January, 2021) (in Arabic).

45. The very rare moment Saddam Hussein announced the cancellation of the 1975 Algiers agreement with Iran in 1980 in front of members of his government. URL: https://youtu.be/7TFeEscJUK4 (accessed: January, 2021) (in Arabic).

Конфликт интересов: о потенциальном конфликте интересов не сообщалось.

Conflict of interest: no potential conflict of interest related to this article was reported.

\section{ИНФОРМАЦИЯ ОБ АВТОРАХ}

Джанаби Якуб Сабих Хасан, аспирант Института международных отношений и мировой истории Национального исследовательского нижегородского государственного университета им. Н.И. Лобачевского, г. Нижний Новгород, Россия.

Надир Мохаммед Салах Эддин, аспирант Института международных отношений и мировой истории Национального исследовательского нижегородского государственного университета им. Н.И. Лобачевского, г. Нижний Новгород, Россия

\section{INFORMATION ABOUT THE AUTHORS}

Yaqoob Sabeeh Hasan Janabi, Postgraduate student of the Institute of International Relations and World History, Lobachevsky State University of Nizhny Novgorod - National Research University, Nizhny Novgorod, Russia

Mohammed Salah Eddin Nadir, Postgraduate student of the Institute of International Relations and World History, Lobachevsky State University of Nizhny Novgorod - National Research University, Nizhny Novgorod, Russia 